\title{
Preliminary assessment for conservation of Pinus cernua (Pinaceae) with a brief synopsis of related taxa in eastern Indochina
}

\section{Исследование сосны плакучей (Pinus cernua, Pinaceae) в целях ее охраны и краткий конспект родственных таксонов в Восточном Индокитае}

\author{
L.V. Averyanov ${ }^{1}$, Khang Sinh Nguyen ${ }^{2}$, Hiep Tien Nguyen ${ }^{3}$, D.K. Harder ${ }^{4}$ \\ Л.В. Аверьянов ${ }^{1}$, Кхан Синь Нгуен ${ }^{2}$, Хьеп Тьен Нгуен ${ }^{3}$, Д.К. Хардер ${ }^{4}$
}

${ }^{1}$ Russian Academy of Sciences, Komarov Botanical Institute, Prof. Popov, 2; St. Petersburg, RF-197376, Russia

${ }^{\prime}$ Ботанический институт им. В.Л. Комарова РАН, ул. Проф. Попова, 2; Санкт-Петербург, 197376, Россия.

E-mail:av_leonid@mail.ru; av_leonid@yahoo.com

${ }^{2}$ Institute of Ecology and Biological Resources, Vietnam Academy of Science and Technology, 18 Hoang Quoc Viet, Cau Giay, Ha Noi, Vietnam; Key Laboratory of Plant Resources Conservation and Sustainable Utilization, South China Botanical Garden,

Chinese Academy of Sciences, Guangzhou 510650, P. R. China; University of Chinese Academy of Sciences, Beijing 100049, P. R. China.

${ }^{2}$ Институт экологии и биологических ресурсов, Академии наук и технологии Вьетнама, 18 Хоанг Куок Виет, Кай Гиау,

Ханой, Вьетнам; Главная лаборатория сохранения и рационального использования растительных ресурсов, Южно-Китайский ботанический сад, Академии наук КНР, Гуанжоу, 510650, КНР; Университет Академии наук КНР, Пекин, 100049,KHP.E-mail: khangnguyensinh@yahoo.com

${ }^{3}$ Center for Plant Conservation, No 25/32, lane 191, Lac Long Quan, Nghia Do, Cau Giay, Ha Noi, Vietnam ${ }^{3}$ Центр охраны растений, о 25/32, линия 191, Лак Лонг Куан, Ни До, Кай Гиау, Ханой, Вьетнам

E-mail:hiep.nguyen@cpcvn.org

${ }^{4}$ Santa Cruz Museum of Natural History \& California Academy of Sciences, 1305 East Cliff Drive, Santa Cruz, California, 95062, U.S.A

${ }^{4}$ Музей Естественной истории в г. Санта-Круз и Академия наук Калифорнии,

Ист Клифф драйв, 1305, Санта-Круз, 95062, Калифорния, США.E-mail: dan@santacruzmuseum.org

Key words: Pinus, Laos, Vietnam, Xuan Nha Nature Reserve, plant diversity, nature protection, plant taxonomy. Ключевые слова: Pinus, Лаос, Вьетнам, заповедник Суан Нха, разнообразие растений, охрана природы, таксономия растений.

Summary. The assessment of a recently discovered Laotian-Vietnamese endemic pine - Pinus cernua (Pinaceae) is presented including new information about species morphology, taxonomy, ecology, distribution, as well as a proposed identification of conservation status according to the IUCN Red List criteria. An annotated list of related pine species known from eastern Indochina also needed updated conservation assessments is provided as well. Four nomenclature combinations - Pinus dalatensis var. anemophila (Businský) Aver., P. dalatensis var. procera (Businský) Aver., P. wangii var. varifolia (Nan $\mathrm{Li}$ et Y.C. Zhang) Aver. and P. wangii var. eremitana (Businský) Aver. are proposed.
Аннотация. В статье представлены оригинальные результаты исследования морфологии, таксономии, экологии, распространения и охранного статуса (IUCN Red List criteria) недавно открытой сосны Pinus cernua (Pinaceae), эндемичной для Лаоса и Вьетнама. Приведен аннотированный список родственных таксонов, встречающихся на территории Восточного Индокитая и остро нуждающихся в охране. Предложено четыре новых номенклатурных комбинации в ранге разновидности: Pinus dalatensis var. anemophila (Businský) Aver., P. dalatensis var. procera (Businský) Aver., P. wangii var. varifolia (Nan Li et Y.C. Zhang) Aver. и P. wangii var. eremitana (Businský) Aver. 


\section{Introduction}

Mountains of eastern Indochina form a series of highlands known today as the Truong Son or Annamese Range. This range stretches as a southeastern extension of the Himalayas for more than $1000 \mathrm{~km}$ from the highlands of Yunnan across the entire peninsular territory to the seashore of southern Cambodia. During the long geological history of the region these mountain chains, running in a longitudinal direction, created a corridor for repeated plant migrations from subtropical and temperate Asia to tropical highlands of Indochina. Ancient plant movements and species isolation within numerous mountain peaks resulted in active processes encouraging species formation within Indochina (Averyanov et al., 2003). Isolation of a number of temperate Asian or Holarctic genera led to the creation of endemic and sub-endemic species within the mountain systems of eastern Indochina. Distribution of Pinus within eastern Indochina is a result of these migrations and subsequent isolation within a number of more or less isolated mountain massifs. As a result, eastern Indochina may constitute the region of the world with the highest diversity of Pinus (Farjon, 2001; Hiep, Vidal, 1996; Hiep et al., 2004; Luu, Thomas, 2004). From 7 to 9 native Pinus species and varieties were inventoried within this territory during recent explorations, observations and taxonomic studies (Businský, 2013; Phan Ke Loc et al., 2013).

The highlands of southern Vietnam provide a home to Ducampopinus krempfii (Lecomte) A. Chev., a unique relictual endemic within the Chu Yang Sin and Bi Dup Mountains. This peculiar primitive pine is possibly the ancestor of all modern pines (Orlova, Averyanov, 2004). This taxon is sometimes regarded as a monotype subgenus of the genus Pinus (Pinus subgen. of Ducampopinus (A. Chev.) Little et Critchfield. Four well defined allopatric varieties of the endemic Pinus dalatensis Ferré - P. dalatensis var. dalatensis, var. anemophila (Businský) Aver., var. bidoupensis Businský and var. procera (Businský) Aver. inhabit isolated mountain areas within southern and central Vietnam and in Laos. A number of isolated massifs of rocky karstic limestone in northern Vietnam and in adjacent regions of China represent the area of distribution of the subendemic $P$. henryi Masters and four calciumdependent endemic races of $P$. wangii $\mathrm{Hu}$ et W.C. Cheng $-P$. wangii var. wangii, var. kwangtungensis (Tsiang) Silba, var. varifolia (Nan Li et Y.C. Zhang) Aver. and var. eremitana (Businský) Aver. Two widespread species, Pinus kesiya Gordon and P. latteri Mason, occasionally form scattered mixed and coniferous forests throughout Indochina. Meanwhile, many mountainous areas of eastern Indochina, particularly regions along the border with Vietnam remain insufficiently explored because they are often inaccessible. Such areas certainly contain the potential for the discovery of numerous local endemic plants during future scientific explorations. The recent discovery of the new 5-leaved pine within the ancient, isolated and highly-eroded sandstone plateau on the border of NE Laos and NW Vietnam is a positive example of this assumption.

This unusual pine was first recognized by Vietnamese geologists at the end of 2011 within the steep cliffs located within the peripheral zone of Pha Luong Mountains and spreading along Laos-Vietnam border between Houaphan and Son La provinces. This remarkable discovery was immediately announced in the January issue of the People's Army Newspaper widely distributed in Vietnam (Lương Tứ Chấn, 2012) and was also noted in a short scientific article in the Vietnam Environment Administration Magazine (Lê Trần Chấn et al., 2012). In 2012 the discovery of the new species was confirmed and voucher herbarium specimens were collected during field work associated within the Rufford grant program - "Conservation of Conifer Tree Species in Hoa Binh - Son La Limestone Corridor" (Nguyen Duc To Luu, 2013; Phan Văn Thăng et al., 2013). These initial assessments and attempts to understand this newly discovered species resulted in its tentative identification as "Pinus aff. armandii Franchet" (Nguyen Duc To Luu et al., 2013; Phan Ke Loc et al., 2013). In their publications, however, these authors indicated certain morphological differences found in the Vietnamese pine from P. armandii (Phan Ke Loc et al., 2013). The preliminary identification of the discovered plant as P. fenzeliana Hand.-Mazz. was additionally proposed on the basis of speculative studies of plant images available on the Internet (Businský, 2013). Further field and laboratory studies by the authors confirmed the obvious differences between the discovered plant from both $P$. armandii and P. fenzeliana, the latter known from isolated locations in southern China. Given the clear distinction of the discovered tree and its morphological differences from all known species of the genus, it was described as a new species under the name Pinus cernua L.K. Phan ex Aver., K.S. Nguyen et T.H. Nguyen in Averyanov et al. (2014: 28). A detailed description and preliminary 
assessment of this very rare endangered species is presented below.

Pinus cernua L.K. Phan ex Aver., K.S. Nguyen et T.H. Nguyen in Aver. et al., 2014, Nordic J. Bot. 32(6): 792. - P. armandii auct. non Franch.: Nguyen Duc To Luu et al., 2013, Proc. $5^{\text {th }}$ Nat. Sci. Conf. Ecol. Biol. Res. (Hanoi): 152; Phan Văn Thăng et al., 2013, Quide Conif. Hoa Binh, Son La prov.: 20; Phan Ke Loc et al., 2013, Ecol. Econ. J. 45: 42. - P. fenzeliana auct. non Hand.-Mazz.: Businský, 2004, Willdenowia 34: 218; id., 2011, Phyton 51, 1: 84; id., 2013, ibid., 53, 2: 247, 257.

Described from the border region of northern Laos and Vietnam ("Laos-Vietnamese border between Son La and Houaphan provinces").

Type. Vietnam, Son La Province, Van Ho District, Chieng Xuan Municipality, Co Hong village, territory of Xuan Nha Nature Reserve, NE. slopes of Pha Luong Mountains. Primary coniferous forest with Pinus cernua on very steep mountain slopes and cliffs composed of brown sandstone at elev. 1000-1050 m a.s.1., 20 $42^{\prime} 14.2 " \mathrm{~N}$, 10443'53.9" E, 12 November 2013, L. Averyanov et al. CPC 6992 (holo - Herbarium of the Center for Plant Conservation!, iso - LE!). Figs 1, locality 7; 2B; 3-5.

Tree 20-30(35) m tall, 0.4-0.8(1) $\mathrm{m}$ dbh. Canopy conical, becoming with irregularly rounded with age; branches suberect to pendulous; leafy branchlets gray-green, olive or yellow-brown, slightly glaucous, glabrous. Bark dull gray-brown to dark brown, roughly fissured into irregular polygonal flat or slightly concave plates, often resinous, inner bark reddish-brown, finely fibrous. Winter buds, orange-brown, often, cylindric, 1-2 cm long, 3-5 $\mathrm{mm}$ in diam.; scales narrowly triangular, (3)4-5 $\mathrm{mm}$ long, 1-2 $\mathrm{mm}$ wide at the base, acuminate, with slightly recurved scarious apex. Needles in fascicles of 5, (12)15-20(22) cm long, 0.6-0.8 mm thick, rich dark green, slender, cernuous, slightly twisted, serrulate, triangular in cross section, with 25-32 rigid erect denticles per $\mathrm{cm}$ along the each edge and with 3-4 stomatal lines on the ventral lateral surfaces; vascular bundle 1, large; resin ducts 3 , subequal, medial and two lateral; the sheath early deciduous. Pollen cones numerous, in spiral clusters

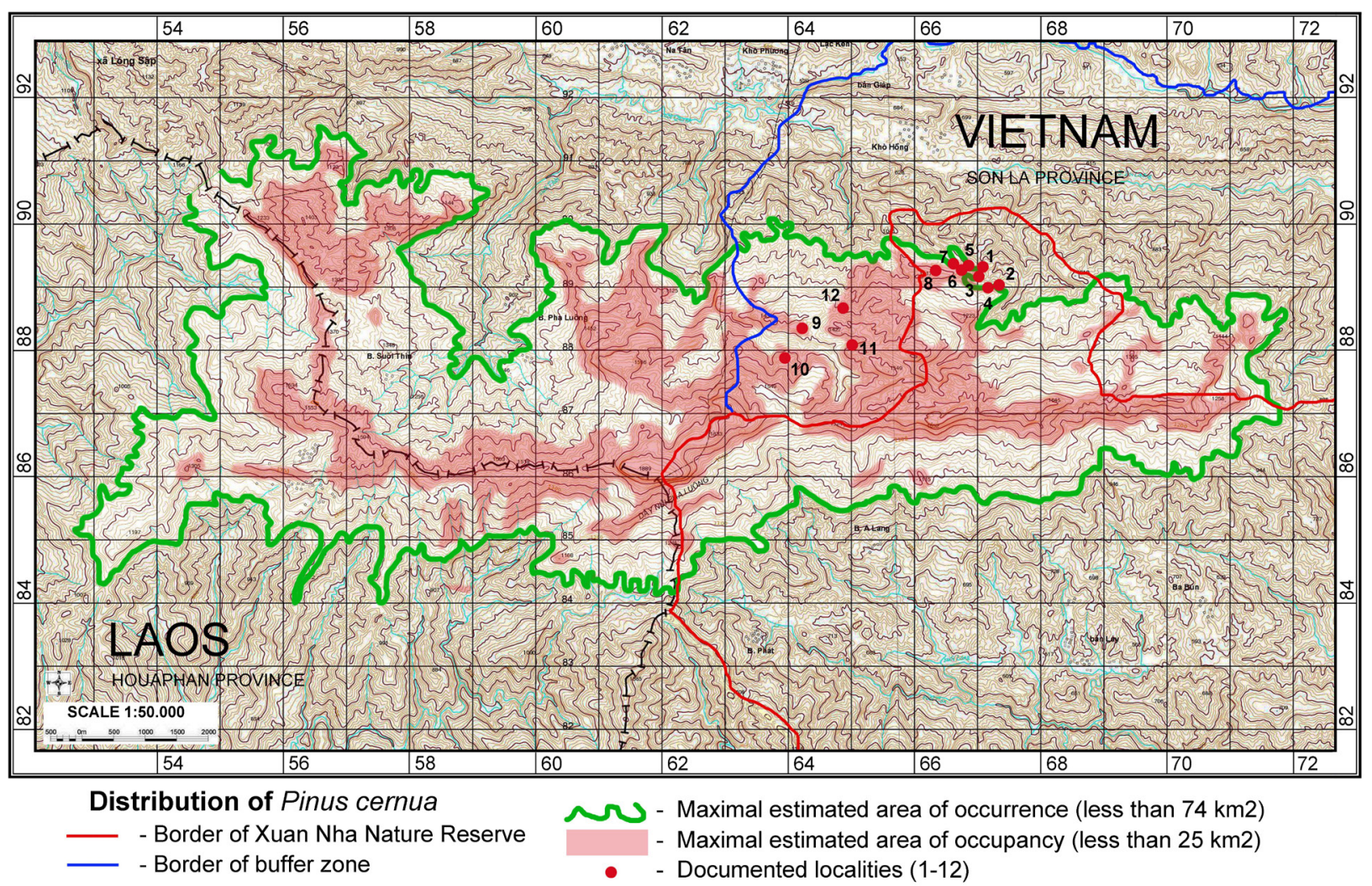

Fig. 1. Expected distribution area of Pinus cernua in the area of Pha Luong Mountains.

Green line designates the maximum estimated area of the species occurrence (less than $74 \mathrm{~km}^{2}$ ); pink shading marks the maximum estimated area of the species occupancy (less than $25 \mathrm{~km}^{2}$ ); red dots (and appropriate black figures) designate the localities where the species was studied; red and blue lines show the border of Xuan Nha Nature Reserve and the border of its buffer zone, respectively. 
at the base of new shoots, ovoid, later elongate, suberect, more or less stout, $0.8-1.5 \mathrm{~cm}$ long, $6-8$ $\mathrm{mm}$ in diam. Seed cones on stout peduncles $1-2 \mathrm{~cm}$ long, commonly clustering 2-6 in a whorl, rarely alone, erect, later facing in all directions, persistent for many years, brown to dark brown, ovoid, 8-11 $\mathrm{cm}$ long, 5-7 $\mathrm{cm}$ in diam., dehiscent at maturity, often profusely resinous. Seed scales woody, rigid, obovate-deltoid, 2.4-2.8(3) $\mathrm{cm}$ long, $1.5-2.5 \mathrm{~cm}$ wide, apophysis deltoid, recurved and thickened at apex in form of transversal finely grooved cushion, umbo insignificant, without mucro. Seeds dark brown, smooth, oblique obovoid, 1-1.2 cm long, $0.5-0.7 \mathrm{~mm}$ in diam., with rudimentary scarious thin wing 1-2 $\mathrm{mm}$ wide disintegrating to seed maturity and occasionally remaining in form of low irregular distal rim. Pollination February-March, seeds September-October.

Paratypes. Vietnam. Sơn La prov., Chiềng Xuân (N.D. Luu et al. 2013): 4 Dec. 2012, P.V. Thăng et al. 5 (VNU, PanNature Herbarium); 13 Dec. 2012, N.Đ.T. Luu et al. 24 (VNU, PanNature Herbarium); 16 Apr. 2013, P.K. Lọc et al. P 11077; 16 Apr. 2013, P 11078-11080; 17 April 2013, P 11081-11082; 18 April 2013, 11084-11089 (LE, VNU, PanNature Herbarium).

Documented photo records. NW Vietnam, border area of Houaphan and Son La Prov., Van Ho
Distr., Chieng Xuan Municipality, Co Hong village, territory of Xuan Nha Nature Reserve, Pha Luong Mt., $20^{\circ} 42^{`} 07.5^{\prime \prime}, \mathrm{N}, 104^{\circ} 40^{`} 41.7^{\prime \prime} \mathrm{E}, 1150 \mathrm{~m}, 12$ Nov. 2013, Averyanov L. et N.S. Khang photos, CPC s.n. (Fig. 2C, locality №8 on Fig. 1); $20^{\circ} 41^{\prime} 39.4^{\prime \prime}, \mathrm{N}$ 104³9‘22.9“" E, 1400 m, 13 Nov. 2013, N.S. Khang photos, CPC s.n. (Fig. 2D, locality №9 on Fig. 1); $20^{\circ} 41^{\prime} 24.7^{\prime \prime} \mathrm{N}, 104^{\circ} 39^{`} 13.8^{\prime \prime} \mathrm{E}, 1380 \mathrm{~m}, 13$ Nov. 2013, N.S. Khang photos, CPC s.n. (Fig. 2E, locality №10 on Fig. 1); 2041‘31.0“ N, 104³9‘53.2“" E, 1450 m, 13 Nov. 2013, N.S. Khang photos, CPC s.n. (Fig. 2F, locality №11 on Fig. 1); $20^{\circ} 41^{\circ} 47.9^{\prime \prime} \mathrm{N}$, $104^{\circ} 39^{‘} 45.6^{\prime \prime} \mathrm{E}, 1430$ m, 13 Nov. 2013, N.S. Khang photos, CPC s.n. (Fig. 2G, locality №12 on Fig. 1). All photos are deposited at the Center for Plant Conservation and LE Herbarium.

All presently known locations based on published data (Nguyen Duc To Luu et al., 2013) and on original source materials are listed in Table 1 and presented on figs 1 and 2 .

Distribution. Endemic of Pha Luong Mountains situated on Laos-Vietnam border between Houaphan and Son La provinces. Hainan?

Ecology and biology. In its known distribution, Pinus cernua, forms primary humid coniferous and mixed forests on steep slopes, cliffs and rocky outcrops of remnant, highly-eroded solid sandstone at elev. (900)1000-1500(1800) m a.s.l. Sometimes it

The list of available locations of $P$. cernua in Pha Luong Mountains

Table 1. presented on figs 1 and 2

\begin{tabular}{|c|c|c|c|}
\hline $\begin{array}{l}\text { № of } \\
\text { location }\end{array}$ & POSITION & ELEVATION & VOUCHER SPECIMENS or/and PHOTOS \\
\hline 1 & $20^{\circ} 42^{\prime} 11^{\prime \prime} \mathrm{N}, 104^{\circ} 41^{\prime} 04^{\prime \prime} \mathrm{E}$ & $949 \mathrm{~m}$ & $\begin{array}{l}\text { P.V. Thang et al. 5, } 4 \text { Dec. 2012; P.K. Loc et al. P } \\
\text { 11077, } 16 \text { Apr. } 2013\end{array}$ \\
\hline 2 & $20^{\circ} 42^{\prime} 07^{\prime \prime} \mathrm{N}, 104^{\circ} 41^{\prime} 12^{\prime \prime} \mathrm{E}$ & $1000 \mathrm{~m}$ & N.Đ.T. Luu et al. 24, 13 Dec. 2012 \\
\hline 3 & $20^{\circ} 42^{\prime} 10^{\prime \prime} \mathrm{N}, 104^{\circ} 41^{\prime} 04^{\prime \prime} \mathrm{E}$ & $955 \mathrm{~m}$ & $\begin{array}{l}\text { P.K. Loc et al. P 11078, 11079, 11080, } 16 \text { April } \\
2013\end{array}$ \\
\hline 4 & $20^{\circ} 42^{\prime} 07^{\prime \prime} \mathrm{N}, 104^{\circ} 41^{\prime} 12^{\prime \prime} \mathrm{E}$ & $1000 \mathrm{~m}$ & P.K. Loc et al. P 11081, 17 April 2013 \\
\hline 5 & $20^{\circ} 42^{\prime} 05^{\prime \prime} \mathrm{N}, 104^{\circ} 41^{\prime} 08^{\prime \prime} \mathrm{E}$ & $1002 \mathrm{~m}$ & P.K. Loc et al. P 11082, 17 April 2013 \\
\hline 6 & $20^{\circ} 42^{\prime} 13^{\prime \prime} \mathrm{N}, 104^{\circ} 40^{\prime} 54^{\prime \prime} \mathrm{E}$ & $1010 \mathrm{~m}$ & $\begin{array}{l}\text { P.K. Loc et al. P 11084, 11085, 11086, 11087, } \\
11088,11089,18 \text { April } 2013\end{array}$ \\
\hline 7 & $20^{\circ} 42^{\prime} 11.4^{\prime \prime} \mathrm{N}, 104^{\circ} 40^{\prime} 53.4^{\prime \prime} \mathrm{E}$ & $1050 \mathrm{~m}$ & Averyanov L. et al. CPC 6992, 12 Nov. 2013 \\
\hline 8 & $20^{\circ} 42^{\prime} 07.5^{\prime \prime} \mathrm{N}, 104^{\circ} 40^{\prime} 41.7^{\prime \prime} \mathrm{E}$ & $1150 \mathrm{~m}$ & $\begin{array}{l}\text { Averyanov L. et N.S. Khang photos, CPC s.n., } 12 \\
\text { Nov. } 2013 \text { (Fig. 2C) }\end{array}$ \\
\hline 9 & $20^{\circ} 41^{\prime} 39.4^{\prime \prime} \mathrm{N}, 104^{\circ} 39^{\prime} 22.9^{\prime \prime} \mathrm{E}$ & $1400 \mathrm{~m}$ & $\begin{array}{l}\text { N.S. Khang photos, CPC s.n., } 13 \text { Nov. } 2013 \text { (Fig. } \\
\text { 2D) }\end{array}$ \\
\hline 10 & $20^{\circ} 41^{\prime} 24.7^{\prime \prime} \mathrm{N}, 104^{\circ} 39^{\prime} 13.8^{\prime \prime} \mathrm{E}$ & $1380 \mathrm{~m}$ & $\begin{array}{l}\text { N.S. Khang photos, CPC s.n., } 13 \text { Nov. } 2013 \text { (Fig. } \\
\text { 2E) }\end{array}$ \\
\hline 11 & $20^{\circ} 41^{\prime} 31.0^{\prime \prime} \mathrm{N}, 104^{\circ} 39^{\prime} 53.2^{\prime \prime} \mathrm{E}$ & $1450 \mathrm{~m}$ & $\begin{array}{l}\text { N.S. Khang photos, CPC s.n., } 13 \text { Nov. } 2013 \text { (Fig. } \\
\text { 2F) }\end{array}$ \\
\hline 12 & $20^{\circ} 41^{\prime} 47.9^{\prime \prime} \mathrm{N}, 104^{\circ} 39^{\prime} 45.6^{\prime \prime} \mathrm{E}$ & $1430 \mathrm{~m}$ & $\begin{array}{l}\text { N.S. Khang photos, CPC s.n., } 13 \text { Nov. } 2013 \text { (Fig. } \\
2 \text { G) }\end{array}$ \\
\hline
\end{tabular}




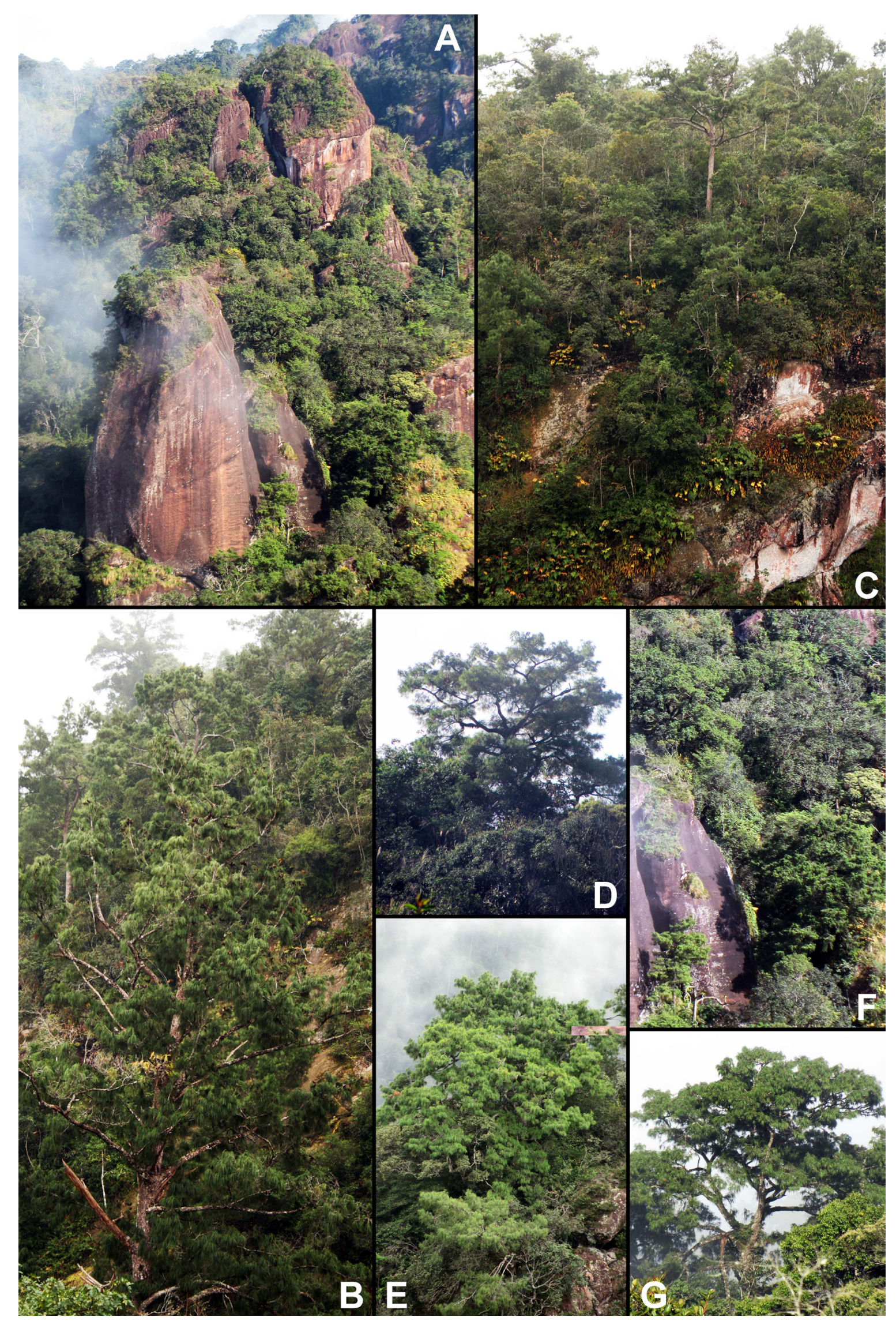

Fig. 2. Habitats and localities of Pinus cernua in Pha Luong Mountains.

A - Typical landscape of the central part of Pha Luong Mountais; B - Mature tree of Pinus cernua in its locus classicus; $\mathrm{C}-\mathrm{G}$ - studied locations of $P$. cernua: $\mathrm{C}$ - locality № $8, \mathrm{D}$ - locality № 9, $\mathrm{E}$ - locality № 10, F - locality № 11, G - locality № 12 . 


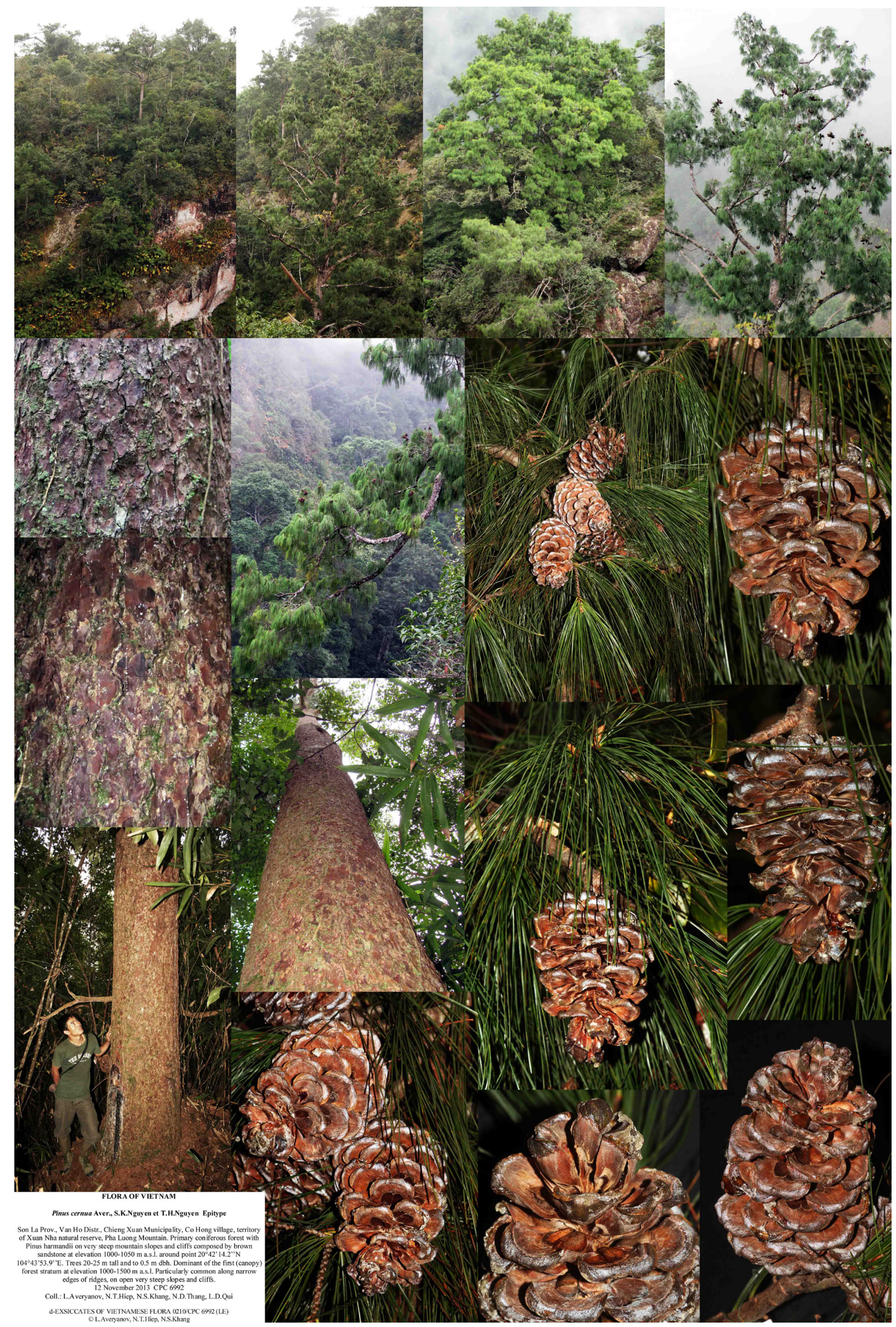

Fig. 3. Pinus cernua in its natural habitat. 


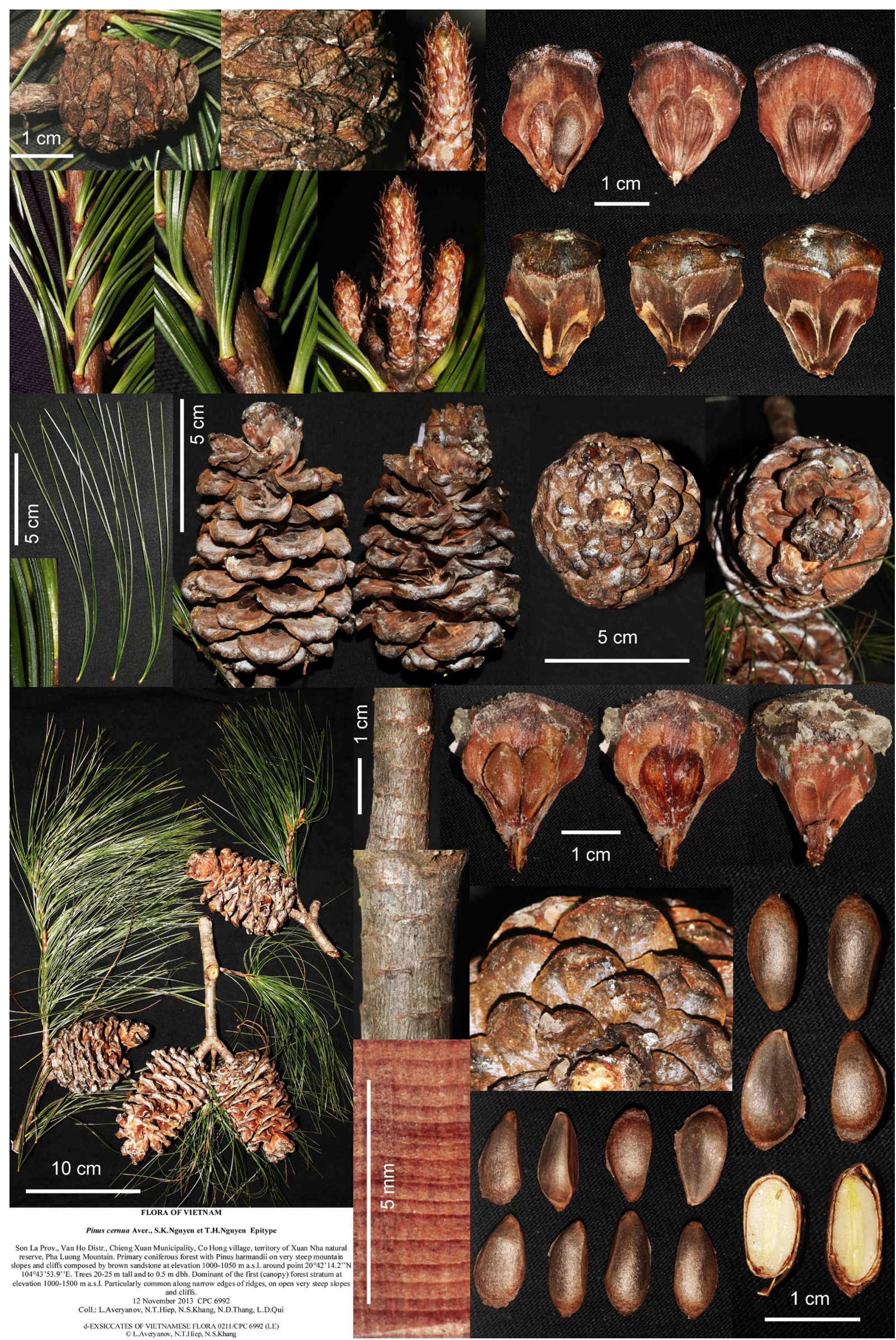

Fig. 4. Digital epitype herbarium sheet of Pinus cernua. 


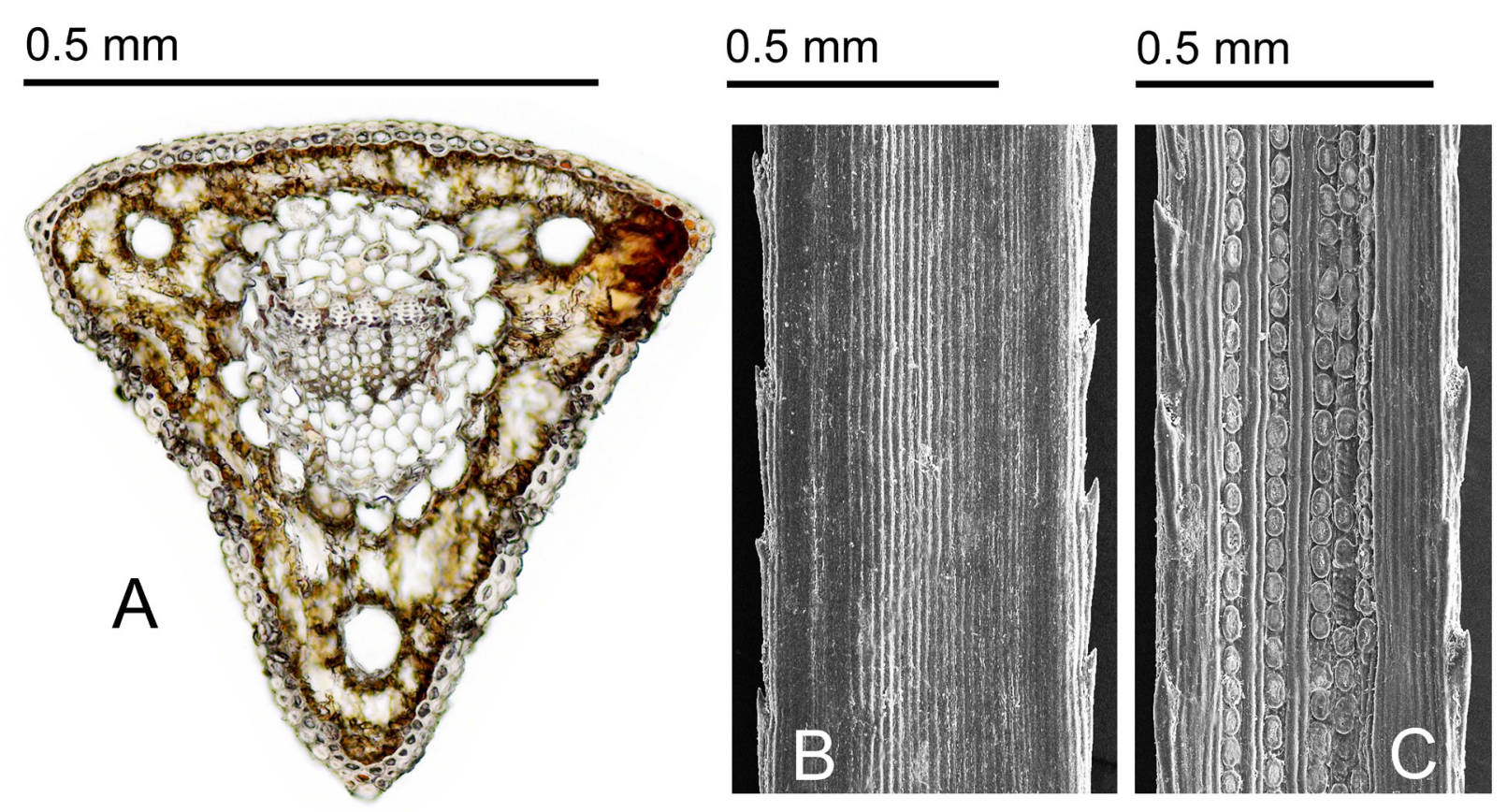

Fig. 5. Microstructure of Pinus cernua needle in its central part.

$\mathrm{a}$ - needle cross section; $\mathrm{b}$ - abaxial surface; $\mathrm{c}$ - lateral adaxial surface (all photos made from herbarium sample P.K. Loc et al. P 11178).

was observed as a scattered tree in closed evergreen, broad-leaved forests. Its occasional gymnosperm associates are Fokienia hodginsii, Dacrycarpus imbricatus and Podocarpus neriifolius.

Seed fertility of $P$. cernua varies between 50 $60 \%$ according to observations on germination of seeds collected during autumn of 2013. In nature it was observed that most seedlings die soon after germination (Phan Ke Loc et al., 2013). Meanwhile, seedlings demonstrate good growth and development under cultivation ex situ at least during first year age (Fig. 6).

Saplings are sporadically found on open rocky slopes and cliff shelves. In shady forests on mountain summits regeneration is very poor or absent. Data are available regarding the successful cultivation by seeds and cuttings (Nguyen Duc To Luu, 2013; Phan Văn Thăng et al., 2013).

Taxonomical notes. The discovered species probably has some relation to the variable complex of Pinus fenzeliana and $P$. armandii. Among a series of infraspecific taxa described in a different rank and associated with the mentioned species, our plant may be closer to the Taiwanese $P$. armandii var. mastersiana (Hayata) Hayata with a very similar morphology of seed cones. At the same time our plant distinctly differs from this taxon in having slender narrow needles more than twice as long as the seed cones, ovoid small persistent seed cones clustering regularly in whorls of 2-6, smaller seed scales with deltoid apophysis recurved and thickened at the apex in the form of a transverse, finely-grooved cushion without a distinct mucro and in seeds with a rudimentary, scarious, early-disintegrating wing. These characteristic features have already been emphasized during the initial studies of the first discovered subpopulation (Nguyen Duc To Luu et al., 2013, Phan Ke Loc et al., 2013). Specimens from Hainan selected as a neotype for P. fenzeliana do not agree with the species protologue (Businský, 2004, 2011). They resemble Vietnamese plants and may be close to our species described here. At the same time according to its original description, $P$. fenzeliana has a distinct morphologic resemblance with the previously described $P$. kwangtungensis Chun ex Tsiang, or it may belong to a hybrid of uncertain origin (Table 2).

Pinus cernua is probably a local endemic of Pha Luong Mountains occuring on the Laos-Vietnamese border between Houaphan and Son La provinces (Nguyen Duc To Luu, 2013; Nguyen Duc To Luu et al., 2013; Phan Ke Loc et al., 2013; Phan Văn Thăng et al., 2013). Deep erosion of the solid orange-brown sandstones forms unique picturesque landforms with numerous rocky ridges, very steep cliff slopes and rocky outcrops on the tops of remnant mesas (Fig. 2A). The species almost exclusively inhabits steep rocky slopes and cliffs (Fig. 2B-G). This distribution may be caused by its zoochores (most likely birds or rodents) delivering seeds into such inaccessible habitats where they can germinate and develop. 
Selected discriminative features between

Pinus fenzeliana, P. kwangtungensis, and P. cernua

\begin{tabular}{|l|l|l|l|}
\hline \multicolumn{1}{|c|}{ FEATURE } & \multicolumn{1}{c|}{$\begin{array}{c}\text { P. fenzeliana } \\
\text { (Handel-Mazzetti, 1931) }\end{array}$} & \multicolumn{1}{c|}{$\begin{array}{c}\text { P. kwangtungensis } \\
\text { (Tsiang, 1948) }\end{array}$} & \multicolumn{1}{c|}{ P. cernua } \\
\hline Needles length & $4-12.5 \mathrm{~cm}$ & $3.5-7 \mathrm{~cm}$ & $(12) 15-22 \mathrm{~cm}$ \\
\hline Needles width & about $0.5 \mathrm{~mm}$ & $1 \mathrm{~mm}$ & $0.6-0.8 \mathrm{~mm}$ \\
\hline Seed strobils form & narrowly ovoid & oblong ovoid & ovoid to broadly ovoid \\
\hline Seed strobils size & $6 \times 3 \mathrm{~cm}$ & $5-6 \times 3.9 \mathrm{~cm}$ & $8-11 \times 5-7 \mathrm{~cm}$ \\
\hline Number of scales in seed come & about 50 & $23-36(79)$ & $50-70$ \\
\hline Scale of seed cone form & late spatulate obovate & obovate quadrate & triangular deltoid \\
\hline Scale of seed cone size & $1.7 \times 1.4-1.8 \mathrm{~cm}$ & $2-3 \times 1.6-2$ & $2.4-3 \times 1.5-2.5 \mathrm{~cm}$ \\
\hline
\end{tabular}

Annual growth of individual trees of $P$. cernua in observed populations is very variable and depends on habitat conditions. Timber of plants found on relatively dry open rocky summits exhibits annual rings $0.5-1.5 \mathrm{~mm}$ wide which indirectly estimates the age of the oldest observed trees of between 200250 years.

The name of the assessed pine, P. cernua, refers to the long slender weeping needles and drooping branches of old trees growing on open rocky cliffs. These features make the plant highly desirable for cultivation as ornamental tree, particularly in rock gardens of the Asian style.

IUCN Red List status and recommendations for conservation. The distribution of $P$. cernua is limited to small, isolated, highly-eroded remnant mountain massifs dissected by deep canyons into numerous narrow ridges on its periphery. Trees grow at elevations above $1000 \mathrm{~m}$ and this restricts the taxon to an area of less than $75 \mathrm{~km}^{2}$ (Fig. 1). Cliff habitats of the species are small in size and are severely fragmented with a total area of occurrence of less than $25 \mathrm{~km}^{2}$ (Fig. 1). The time to species regeneration is uncertain, but it is highly probable that a single generation would exceed 50 years. In this circumstance the decline of the populations of $25 \%$ (or more) during one generation may be reasonably expected, though within some parts of the range of the species (within Vietnam) fits within the area of Xuan Nha Nature Reserve. On the basis of these conditions, the species may be preliminarily assessed (IUCN 2013) both in Lao P.D.R. and Vietnam as a critically endangered (CR) under formal IUCN Red List criteria - Blab(i, iii), $\mathrm{C} 1, \mathrm{C} 2 \mathrm{a}(\mathrm{ii})$. Occasional, uncontrolled forest fires, sporadic logging, deforestation and loss of habitats are main threats for the species. Protection and monitoring of all known subpopulations, artificial propagation and introduction into cultivation as an ornamental tree may be effective measures to support species conservation.

Related 5-leaved species and varieties known in eastern Indochina also need modern assessment for their conservation protection in the region are listed below with notes on their taxonomy, distribution and ecology.

Five-leaved pine species occurring in eastern Indochina presently in need of assessment for their protection

1. Pinus dalatensis Ferré, 1960, Trav. Lab. Forest. Toulouse 1, 4, 4: 8.

1a. Pinus dalatensis var. dalatensis $-P$. wallichiana A.B. Jacks. var. dalatensis (Ferré) Silba, 1984, Phytologia Mem. 7: 59.

Described from S Vietnam. Type: Vietnam, Phan Rang, Trai Mat, a 6 km de Da Lat Dec. 1957, Gaussen s.n. (TL).

Distribution. S Vietnam (Lam Dong). SE Laos (Attapeu, Xekong)?

Ecology. Mixed and coniferous primary forests on silicate rocks, preferably granite and gneiss at elev. 1500-2600 m a.s.1.

1b. Pinus dalatensis var. anemophila (Businský) Aver., comb. et stat. nov. - P. anemophila Businský, 2010, Acta Pruhonic. 96: 5.

Described from central Laos. Type: Laos, Khammouan Province, E margin of Phou Ak plateau above Mu Gia Pass, ca $200 \mathrm{~m} \mathrm{~W}$ from plateau edge with Vietnam frontier W above road from the Cha Lo border checkpoint to the border pass ... alt. 995 $\mathrm{m}, 17^{\circ} 40.20 .8 " \mathrm{~N}, 105^{\circ} 44.54 .5 " \mathrm{E}, 22.04 .2010$, Businsky 68102 (holo - PR; iso - BM, G, MO, P).

Distribution. Central Vietnam (Quang Binh), central Laos (Khammouan, Saravan). 
Ecology. Mixed and coniferous primary forests on rocky shale and sandstone plateaus at elev. 800$1200 \mathrm{~m}$ a.s.1.

1c. Pinus dalatensis var. bidoupensis Businský, 1999, Candollea 54: 127. - P. dalatensis subsp. bidoupensis (Businský) Silba, 2009, Journ. Intern. Conif. Preserv. Soc. 16, 1: 19.

Described from S Vietnam. Type: Vietnam, Lam Dong and Thuan Hai Prov. border NE of Dalat, Bi Doup (2287 m) mt. region, W slopes of massif 2010

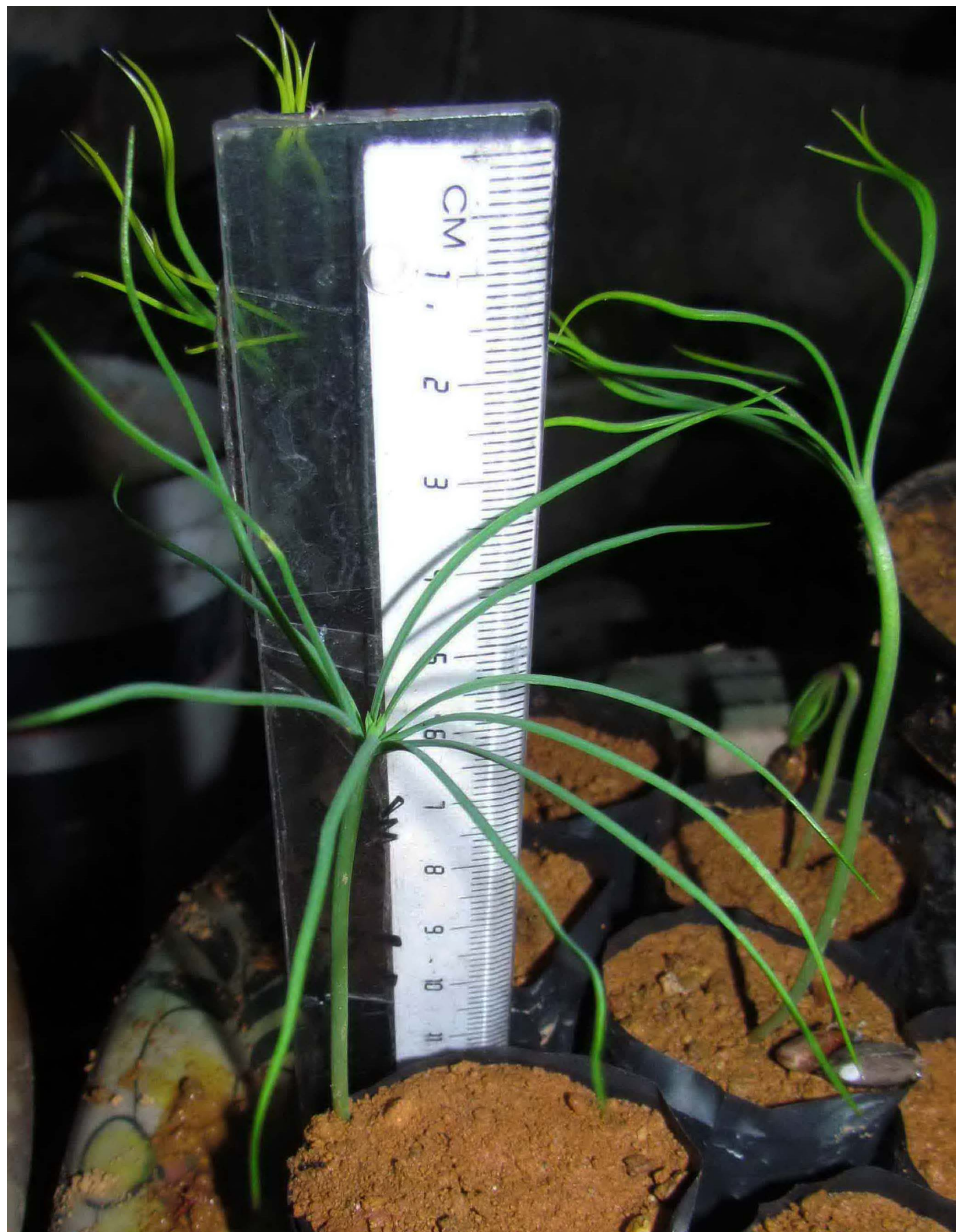

Fig. 6. Seedling of Pinus cernua under cultivation 3 month after germination. 
m sit. $6 \mathrm{~km}$ SE of Bi Doup, a flat ridge approx. 1 km WNW of elev. point $1978 \mathrm{~m}$; dense mixed forest together with Pinus krempfii et Fokienia hodginsii; 1895 m a.s.1.; $12^{\circ} 02^{\prime} 30^{\prime \prime} \mathrm{N}, 108^{\circ} 41^{\prime} 55^{\prime \prime} \mathrm{E} ; 17.02$. 1994, R. Businský 39160 (holo - G; iso - HN, K).

Distribution. S Vietnam (Dak Lak, Lam Dong, Ninh Thuan, Khanh Hoa).

Ecology. Mixed and coniferous primary forests on shaly and granite mountains at elev. 1400-2000 $\mathrm{m}$ a.s.1.

1d. Pinus dalatensis var. procera (Businský) Aver., comb. nov. $-P$. dalatensis subsp. procera Businský, 1999, Candollea 54: 133. - P. fenzeliana Hand.-Mazz. var. annamiensis Silba, 2000, Journ. Intern. Conif. Preserv. Soc. 7, 1: 30. - P. fenzeliana subsp. annamiensis (Silba) Silba, 2009, Journ. Intern. Conif. Preserv. Soc. 16, 1: 21.

Described from $S$ Vietnam without exact locality. Type: Annam: Thua-Luu, Forêt de Duông, coll. Service forestier 14 May 1918, A. Chevalier 38353 (holo-P).

Distribution. S Vietnam (Gia Lai, Kon Tum, Quang Nam, Thua Thien - Hue). Laos (Sekong)?

Ecology. Mixed and coniferous primary forests on shale and granite mountains at elev. 800-2500 m a.s.l.

2. Pinus fenzeliana Hand.-Mazz., 1931, Oesterreich. Bot. Zeit. 80: 337. - P. armandii Franch. var. fenzeliana (Hand.-Mazz.) Eckenwalder, 2009, Conif. World: 647.

Described from Hainan. Type: China, Hainan: "In silvis montium Hungmoleng et Ngitse-leng dispersa inter arbores sempervirentes, in utroque semel tantum inventa, $1000 \mathrm{~m}$ X-XI 1929, Fenzel 55 " - probably lost, non neotype: "China, Hainan Island, central part, Ying Ge Ling massif (1822 m), E-NE slopes above road pass NE of elev. point 1822 $\mathrm{m}$, below lateral $\mathrm{N}$ ridge on a beginning steep stony ENE declivity, together with bamboo, $1040 \mathrm{~m}$, 1904'20" N, 109³2'30" E, 22. 12. 1993, Businský 39103" (B, G, BM, MO, P, PE, PR, W) (Businský 2004: 218).

Distribution. N Vietnam? S China (Guangxi, Guizhou, Hainan, SE Sichuan).

Ecology. In China mixed mountain forests on silicate rocks at elev. 1000-1600 m a.s.l. (Liguo Fu et al., 1999).

3. Pinus wangii $\mathrm{Hu}$ et W.C. Cheng, 1948 (15 May), Bull. Fan Mem. Inst. Biol. n.s. 1, 2: 191.

3a. Pinus wangii var. wangii - P. parviflora var. wangii (Hu et W.C. Cheng) Eckenwalder, 2009, Conif. World: 647.
Described from SE Yunnan. Type: China, Yunnan: ... Mar-li-po, Hwang-gin-yin, alt. 1100 m, on rocky hills ... "C.W. Wang 85830 (holo - KUN; iso - PE № 1599294). Proposed lectotypification of $P$. wangii by the duplicate at PE (Lin Qi, Cao Zi-yu, 2007) was unnecessary as the type specimen ("C.W. Wang 85830") was clearly designated as the "type" in the species protologue and its location at KUN was explicitly stated (Hu, Cheng 1948).

Distribution. N Vietnam (Ha Giang, Cao Bang), S China (SE Yunnan, S Kwangsi).

Ecology. Mixed and coniferous primary forests on rocky limestone at elev. 1000-1400 m a.s.l.

3b. Pinus wangii var. kwangtungensis (Chun ex Tsiang) Silba, 1990, Phytologia 68, 1: 64. - P. kwangtungensis Chun ex Tsiang, [Nov.] 1948, Sunyatsenia 7, 1-2: 113. - P. wangii subsp. kwangtungensis (Chun ex Tsiang) Businský, 1999, Acta Pruhon. 68: 11. - P. fenzeliana Hand.-Mazz. subsp. kwangtungensis (Chun ex Tsiang) Silba, 2009, Phytologia 68, 1: 21.

Described from S China ("Hainan: ... Kwangtung: ... Kwangsi: ... Hunan: ...”). Type: China, Kwangtung: Loh-Chang, in scrub, tree $13 \mathrm{~m}$, 17 VI 1929, C.L. Tso 21130 (holo - SYS).

Distribution. NW Vietnam? S China (N Guangdong, S Guizhou, Hainan, S Hunan).

Ecology. Mixed and coniferous primary forests on silicate rocks at elev. 700-1600 m a.s.l., commonly on rocky steep slopes and ridge edges.

3c. Pinus wangii var. varifolia (Nan Li et Y.C. Zhong) Aver. comb. nov. - P. kwangtungensis Chun ex Tsiang var. varifolia Nan Li et Y.C. Zhong, 1997, Novon 7, 3: 262. - P. wangii $\mathrm{Hu}$ et W.C. Cheng subsp. varifolia (Nan Li et Y.C. Zhong) Businský, 1999, Acta Pruhon. 68: 11. - P. fenzeliana Hand.Mazz. subsp. varifolia (Nan Li et Y.C. Zhong) Silba, 2009, Journ. Intern. Conif. Preserv. Soc. 16, 1: 38.

Described from SW Guangxi. Type: China, Longing Xian, Tiandeng Xian, summits of limestone mountains, ca. $540 \mathrm{~m}$, Y.C. Zhong 80834 (holo - PE; iso - GXF).

Distribution. NE Vietnam (Bac Kan, Cao Bang, Lang Son), S China (Guangxi, S Guizhou).

Ecology. Mixed and coniferous primary forests on rocky limestone at elev. (500)800-1200 m a.s.l.

3d. Pinus wangii var. eremitana (Businský) Aver., comb. et stat. nov. - P. eremitana Businský, 2004, Willdenowia 34: 234.

Described from NW Vietnam. Type: Vietnam, Son La Prov., E border near Ha Son Binh Prov., the karstic hills approx. $1.5-2 \mathrm{~km} \mathrm{~W}$ of Pa Co village NW of Mai Chau ... 1480 m, 20 ${ }^{\circ} 45^{\prime} \mathrm{N}, 1^{104^{\circ}} 53^{\prime} \mathrm{E}$, 
01. 02. 1994, Businsky 39133 (holo - PR; iso - B, G, HN, K, MO, P).

Distribution. NW Vietnam (Hoa Binh, Son La, Thanh Hoa), NE Laos (Houaphan)?

Ecology. Mixed and coniferous primary forests on rocky limestone at elev. 1100-1500 m a.s.l.

Acknowledgements. Results of field investigations presented in this paper were supported by a grant from the U.S.A. National Geographic Society titled "Exploration of primary woods along constructed highway Hanoi - Ho Chi Minh for their sustainable conservation (in limits of $\mathrm{Ha}$ Tinh and Nghe An provinces of central Vietnam)". We are grateful to Dr. K. Demchenko and Mrs. L. Kartzeva for their kind help in the studies of needle microstructure as well as Dr. A. Sennikov for his valuable critical comments.

\section{REFERENCES}

Averyanov L.V., Loc P.K., Hiep N.T., Harder D.K. Phytogeographic review of Vietnam and adjacent areas of Eastern Indochina // Komarovia, 2003. - Vol. 3. - P. 1-83.

Averyanov L.V., Tien Hiep Nguyen, Khang Nguyen Sinh, The Van Pham, Vichith Lamxay, Somchanh Bounphanmy, Shengvilai Lorphengsy, Loc Ke Phan, Soulivanh Lanorsavanh, Khamfa Chantthavongsa. Gymnosperms of Laos // Nordic Journal of Botany, 2014. - Vol. 32, № 6. - P. 765-805 (doi: 10.1111/njb.00498).

Businský $\boldsymbol{R}$. Study of Pinus dalatensis Ferre and of the enigmatic "Pin du Moyen Annam" // Candollea, 1999a. Vol. 54. - P. 125-143.

Businský R. Taxonomic revision of Eurasian pines (genus Pinus L.). Survey of species and infraspecific taxa according to latest knowledge // Acta Pruhoniciana, 1999b. - Vol. 68. - P. 7-86.

Businský R. A revision of the Asian Pinus subsection Strobus (Pinaceae) // Willdenowia, 2004. - Vol. 34. P. 209-257.

Businský $\boldsymbol{R}$. A new species of soft pine from the Vietnamese border of Laos // Acta Pruhoniciana, 2010. - Vol. 96. - P. 5-13.

Businský R. Pinus fenzeliana Hand.-Mazz. (Pinaceae) still misinterpreted? // Phyton, 2011. - Vol. 51, № 1. P. 77-87.

Businský R. Taxonomic revision and conspectus of Pinus in Vietnam // Phyton, 2013. - Vol. 53, № 2. - P. 241-264.

Eckenwalder J.E. Conifers of the World: the complete reference. - Portland \& London: Timber Press, 2009. $704 \mathrm{p}$.

Farjon A. World checklist and bibliography of conifers. Ed. 2. - Kew: Kew Publishing, Royal Botanic Gardens, 2001. -309 p.

Ferre $\boldsymbol{Y}$. Une nouvelle espece de pin au Viet-Nam Pinus dalatensis // Bulletin Society Histoire Naturelle Toulouse, 1960. - Vol. 95. - P. 171-180.

Franchet M.A. Plantae davidianae ex Sinarum Imperio // Nouvelles Archives du Museum d'Histoire Naturelle, 1884. - Ser. 2, T. 7. - P. 55-172.

Handel-Mazzetti H. Kleine Beiträge zur Kenntnis der Flora von China. // Österreichische Botanishe Zeitschrift, 1931. - Vol. 80. - P. 337-338.

Hiep N.T., Vidal J.E. Gymnospermae // Ph. Morat (ed.). Flore du Cambodge du Laos et du Vietnam. - Vol. 28. Paris: Museum National d'histoire naturelle, 1996. -166 p.

Hiep N.T., Loc P.K., Luu N.D.T., Thomas P.I., Farjon A., Averyanov L., Regalado J.Jr. Vietnam conifers conservation status review 2004. - Cambridge: Fauna \& Flora International, 2004. - 129 p.

Hu H.H., Cheng W.C. Some new trees from Yunnan // Bulletin of the Fan Memorial Institute of Biology, 1948. New Series 1, № 2. - P. 191-198.

IUCN. IUCN Red List of Threatened Species. 2013. Version 2013.2. <www.iucnredlist.org>, accessed 14 Aug. 2014.

Lê Trần Chấn, Nguyễn Hũu Tứ and Nguyễn Viết Luơng. Phát hiện loài Thông 5 lá mới ở Sơn La (Discovery of new 5 needle pine from Son La) // Tạp chí Môi trường (Vietnam Environment Administration Magazine), 2012. - Vol. 2. - P. 52 (in Vietnamese).

Liguo Fu, Nan Li, Elias T.S., Mill R.R. Pinaceae // Zh.G. Wu, P.H. Raven, Hong D.Y. (eds). Flora of China. - Vol. 4. - Beijing: Science Press \& St. Louis: MBG Press, 1999. - P. 11-52.

Lin Qi, Cao Zi-yu. Lectotypification of four names of Chinese taxa in Gymnospermae // Acta Botanica Yunnanica, 2007. - Vol. 29, № 3. - P. 291-292.

Lương Tú Chấn. Phát hiện loài Thông 5 lá mới ở Sơn La (Discovery of new 5 needle pine from Son La) // Báo Quân Đội Nhân Dân (People’s Army newspaper), 2012. - 15 January 2012. - P. 4 (in Vietnamese).

Luu N.D.T., Thomas P. Conifers of Vietnam: an illustrated field guide. - Hanoi: World Publishing House, 2004. 121 p. (in Vietnamese). 
Nan $\mathbf{L i}, \boldsymbol{F u} \mathbf{L} .-K$. Notes on Gymnosperms I: Taxonomic treatments of some Chinese conifers // Novon, 1997. Vol. 7, № 3. - P. 261-264.

Nguyen Duc To Luu. Conservation of conifer tree species in Hoa Binh - Son La Limestone Corridor. - The Rufford Foundation, 2013. <http://www.rufford.org/rsg/projects/nguyen_duc_luu>, accessed 25 March 2014.

Nguyen Duc To Luu, Phan Van Thang, Dang Xuan Truong, Ha Cong Liem, Phan Ke Loc. Pinus aff. armandii Franch., five needle pine, new occurrence for the conifer flora of Vietnam // Proc. of the $5^{\text {th }}$ National Scientific Conference on Ecology and Biological Resources (IEBR), 2013. - Hanoi: Agric. Publ. House. - P. $152-156$ (in Vietnamese, resume in English).

Orlova L.V., Averyanov L.V. On the taxonomical position of Ducampopinus krempfii (Pinaceae) // Turczaninowia, 2004. - Vol. 7, № 2. - P. 30-44.

Phan Ke Loc, Pham Van The, Nguyen Sinh Khang, Nguyen Thi Thanh Huong, Averyanov L.V. Native conifers of Vietnam. Updated checklist 2013 // Ecology Economy Journal, 2013. - Vol. 45. - P. 33-50 (in Vietnamese, resume in English).

Phan Văn Thăng, Đặng Xuân Trưòng, Nguyễn Đức Tố Lưu and Hà Công Liêm. Chỉ dẫn về. Cac loai thong ở vùng núi Mai Châu - Mộc Châu tỉnh Hòa Bình - Sơn La (Guide for conifers in moutainous areas of Mai Chau-Moc Chau, Hoa Binh and Son La province), 2013. - Hà Nội: Nhà Xuất Bản Nông Nghiệp (Agriculture Publishing House). 48 p. (in Vietnamese) <http://nature.org.vn/vn/2013/10/chi-dan-ve-cac-loai-thong>, accessed 14 Aug. 2014.

Silba J. An international census of the Coniferae I // Phytologia Memoirs, 1984. Vol. 7. - P. 1-79.

Silba J. A supplement to the international census of the Coniferae II // Phytologia, 1990. - Vol. 68, № 1. - P. 7-79. Silba $\mathbf{J}$. Variation geographic et populations isole de les gymnospermes rarissime // Journal of the International Conifer Preservation Society, 2000. - Vol. 7, № 1. - P. 17-40.

Silba J. An international census of the Conifereae, II, The Pinaceae, 2 (Cedrus and Pinus) // Journal of the International Conifer Preservation Society, 2009. - Vol. 16, № 1. - P. 13-38.

Tsiang Ying. A new pine from south China // Sunyatsenia, 1948. - Vol. 7, № 1-2. - P. 111-114. 